\title{
Biology and genetic improvement of Jatropha curcas L.: A review
}

\author{
B.N. Divakara ${ }^{\mathrm{a}, *}$, H.D. Upadhyaya ${ }^{\mathrm{a}, 1}$, S.P. Wani ${ }^{\mathrm{b}, 2}$, C.L. Laxmipathi Gowda ${ }^{\mathrm{a}, 3}$ \\ ${ }^{a}$ Global Theme on Crop Improvement, International Crops Research Institute for the Semi Arid Tropics, Patancheru - 502 324, Hyderabad, Andhra Pradesh, India \\ ${ }^{\mathrm{b}}$ Global Theme of Agroecosystems, International Crops Research Institute for the Semi Arid Tropics, Patancheru - 502 324, Hyderabad, Andhra Pradesh, India
}

\section{A R T I C L E I N F O}

\section{Article history:}

Received 19 March 2009

Received in revised form 15 July 2009

Accepted 17 July 2009

Available online $\mathrm{xxxx}$

\section{Keywords:}

Jatropha curcas

Floral biology

Genetic improvement

\begin{abstract}
A B S T R A C T
Bio-diesel is a fast-developing alternative fuel in many developed and developing countries of the world. The bio-diesel production from vegetable oils during 2004-2005 was estimated 2.36 million tonnes globally. Of this, EU countries accounted for about $82 \%$ and USA about $6 \%$. Global bio-diesel production is set to reach some 24 billion litres by 2017. Shortage of edible oil for human consumption in developing countries does not favour its use for bio-diesel production. Hence non-edible oil from crops like Jatropha (Jatropha curcas) and Pongamia (Pongamia pinnata) is favoured for bio-diesel production and the trend is expected to continue. Especially J. curcas has gained attention in tropical and sub-tropical countries and has spread beyond its centre of origin, because of its hardiness, easy propagation, drought endurance, high oil content, rapid growth, adaptation to wide agro-climatic conditions, and multiple uses of plant as a whole. The full potential of $J$. curcas has not been realized due to several technological and economic reasons. One of the major reasons is the lack of high yielding varieties with high oil content. In this review, we attempt to discuss the currently available information on Jatropha species identity, taxonomy and description, distribution and ecological requirements of the species, possibilities of exploitation of genetic potentiality, exploitation of existing diversity for yield and oil content by direct selection, hybridization and creation of diversity by mutation, and biotechnological interventions.
\end{abstract}

(c) 2009 Elsevier Ltd. All rights reserved.

\section{Contents}

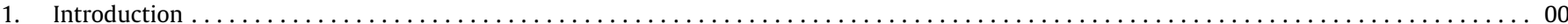



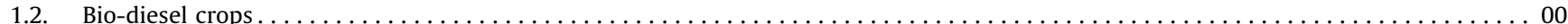

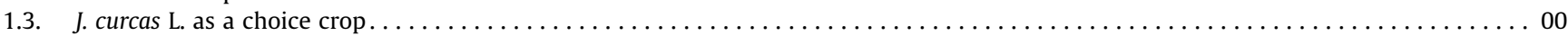

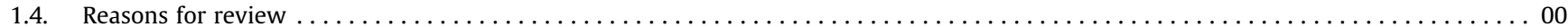

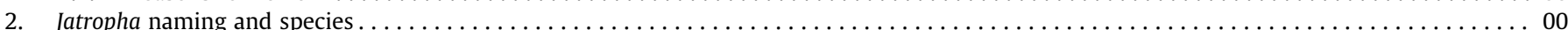

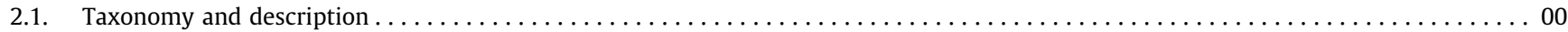

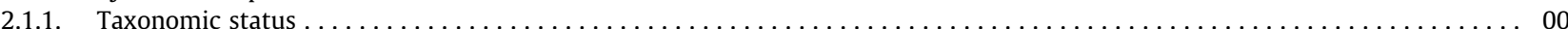

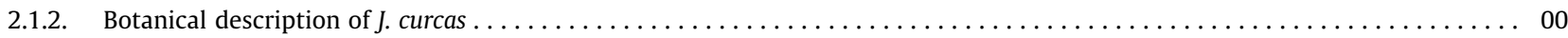

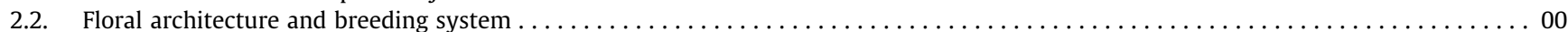

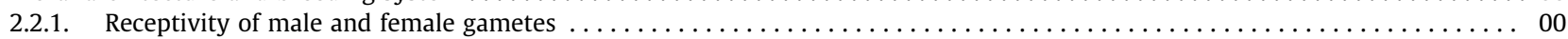

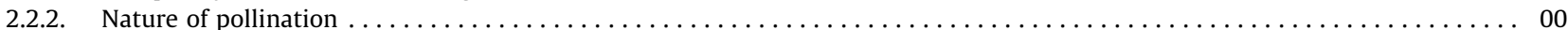

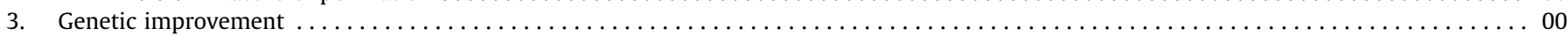

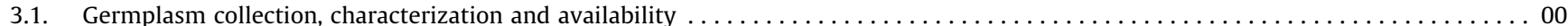

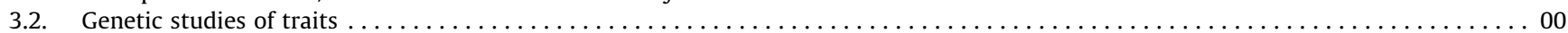

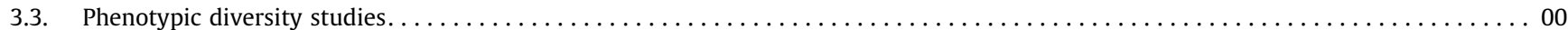

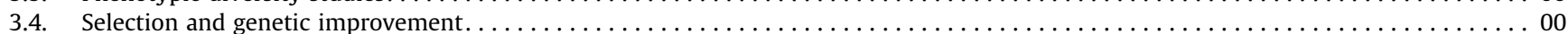

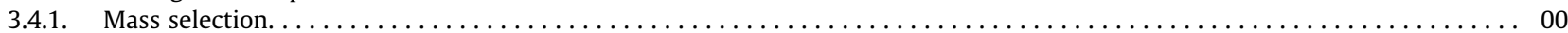

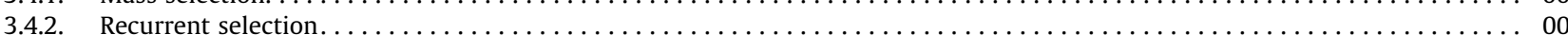

* Corresponding author. Tel.: +91 4030713329; fax: +91 4030713074 .

E-mail addresses: bn.divakara@cgiar.org (B.N. Divakara), h.upadhyaya@cgiar.org (H.D. Upadhyaya), s.wani@cgiar.org (S.P. Wani), c.gowda@cgiar.org (C.L. Laxmipathi Gowda).

${ }^{1}$ Tel.: +914030713333 .

2 Tel.: +914030713466.

${ }^{3}$ Tel.: +914030713354 .

0306-2619/\$ - see front matter @ 2009 Elsevier Ltd. All rights reserved. doi:10.1016/j.apenergy.2009.07.013 


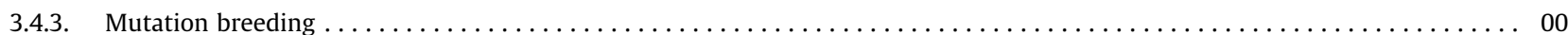

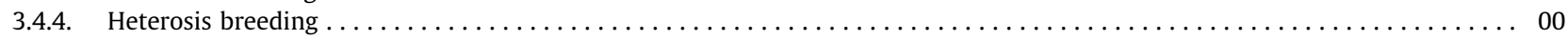



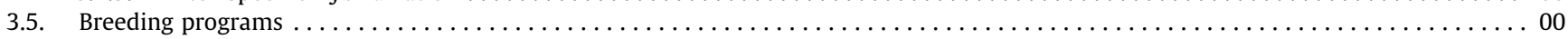

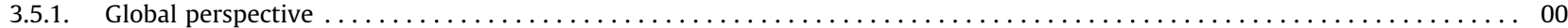

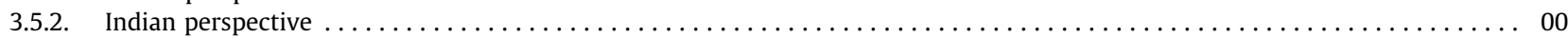

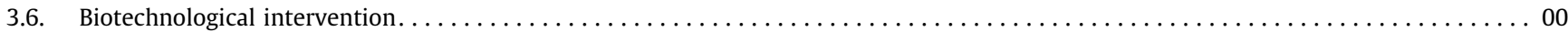

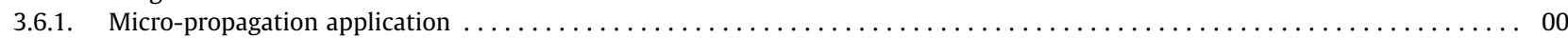

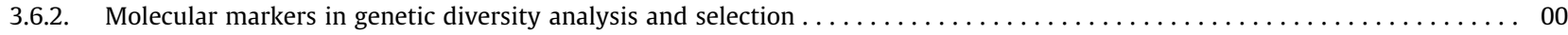

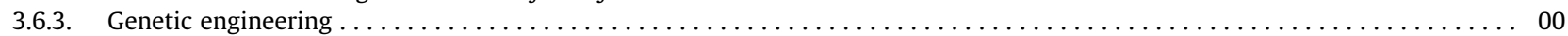

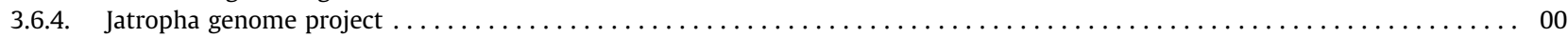

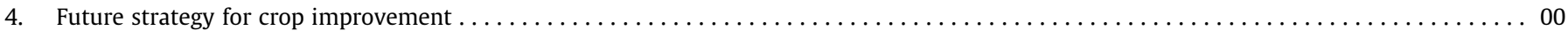

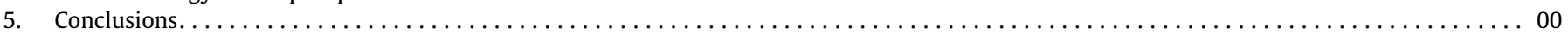

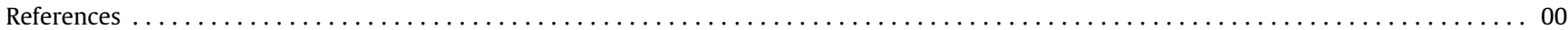

\section{Introduction}

\subsection{Global status of bio-diesel requirement}

Biomass as a source of renewable energy is fundamental for development and sustenance of civilization. In view of growing interest for renewable energy sources, liquid bio-energy production from vegetable oils is one of the possible options to reduce greenhouse gas (GHG) emissions. Bio-diesel production from vegetable oils during 2004-2005 was estimated to be 2.36 million tonnes globally. Of this, EU countries (1.93 million tonnes) with expectation of $30 \%$ annual increase and the USA ( 0.14 million tonnes) together accounted for $88 \%$ and rest of the world ( 0.29 million tonnes) for the remaining $12 \%$ [1]. Global bio-diesel production is set to grow at slightly higher rate than bio-ethanol and will reach 24 billion litres by being the largest share by 2017 [2].

\subsection{Bio-diesel crops}

Bio-diesel is expanding very fast because of demand, necessary policy support and technological availability. India consumes approximately 40 million tonnes of diesel and ranked fifth in the world after the US, China, Russia and Japan in terms of fossil fuel consumption. Recently, Government of India launched "National Mission on Bio-diesel" with a view to find a cheap and renewable liquid fuel based on vegetable oils [3]. However, shortage of raw material to produce bio-diesel is a major constraint [4]. The total number of oil-bearing species range from 100 to 300 , and of them 63 belonging to 30 plant families hold promise for bio-diesel production [5]. Many developed countries are using edible oil-seed crops such as soybean, rapeseed, groundnut, sunflower for production of bio-diesel. However, developing countries like India, having dearth of huge quantity of edible oil (6.31 million tonnes) for consumption, cannot afford to use edible oils for bio-diesel production and hence non-edible oil seeds such as Pongamia (Pongamia pinnata) and Jatropha (Jatropha curcas) are explored along with meeting additional criteria of greening the wastelands without compromising the food, fodder security and improve livelihoods $[4,6]$. Thus, J. curcas which meets the American and European standards, gained importance in tropical and sub-tropical countries [7].

\subsection{J. curcas L. as a choice crop}

J. curcas is native of tropical America, but is now found abundantly in many tropical and sub-tropical regions throughout Africa and Asia because of likely distribution by Portuguese ships via the Cape Verde islands and Guinea Bissau [8]. J. curcas has spread beyond its original distribution because of its hardiness, easy propagation, drought endurance, high oil content, low seed cost, short gestation period, rapid growth, adoption to wide agro-climatic condition, bushy/shrubby nature and multiple uses of different plant parts [9-11]. Added to this, qualitative sustainability assessment, focusing on environmental impacts and strengthened by some socioeconomic issues, is quite favorable as long as jatropha is cultivated on wastelands/degraded lands [12]. In view of these advantages, many investors, policy makers and clean development mechanism (CDM) project developers are interested to tackle the twin challenges of energy supply and GHG emission reduction.

\subsection{Reasons for review}

For several reasons, both technical and economical, the full potential of $J$. curcas is far from being realized. Apart from agronomic, socioeconomic and institutional constraints, planned crop improvement programs are lacking globally. Earlier research programs involving large-scale plantations launched in Brazil, Nicaragua and India indicated that the crop productivity is far too low to be commercialized. In extreme cases, the plantations failed to produce fruits. There is limited information available on genetics and agronomy of jatropha. There is lack of bench mark descriptors and information on genetic variability, effects of environment and genotype $\times$ environment $(G \times E)$ interaction [13]. Furthermore, there is a need for integration of the available scattered knowledge on, and experiences with crop performance of different $J$. curcas provenances in different environments and management interventions. Keeping this in view, an attempt is made to review available literature on genetic improvement of $J$. curcas from various journals, articles, reports and conference proceedings to cover wider range of information.

\section{Jatropha naming and species}

Current name is $J$. curcas Linnaeus (Euphorbiaceae). Linnaeus [14] was the first to name the physic nut J. curcas L. The genus name Jatropha derives from the Greek word jatros (doctor) and trophe (food), which implies its medicinal uses. According to Dehgan and Webster [15] and Schultze-Motel [16], synonyms of the physic nut are: Curcas purgans Medik.; Ricinus americanus Miller.; Castiglionia lobata Ruiz \& Pavon.; Jatropha edulis Cerv.; J. acerifolia Salisb.; Ricinus jarak Thunb.; Curcas adansoni Endl.; Curcas indica A. Rich.; Jatropha yucatanensis Briq.; Curcas curcas (L.) Britton \& Millsp. Table 1 presents vernacular names.

\subsection{Taxonomy and description}

\subsubsection{Taxonomic status}

The genus Jatropha belongs to tribe Joannesieae of Crotonoideae in the Euphorbiaceae family, and contains approximately 175 
Table 1

Common/vernacular names Jatropha curcas.

\begin{tabular}{ll}
\hline Language/country & Name \\
\hline English & purging nut \\
French & pourghère, pignon d'Inde \\
Dutch & purgeernoot \\
German & purgiernuß, Brechnuß \\
Portuguese & purgueira \\
Italian & fagiola d'India \\
Arab & dand barrî, habel meluk \\
Sanskrit & kanananaeranda, parvataranda \\
Hindi (India) & ratanjyot, bagbherenda, jangli arandi, safed arand, bagaranda \\
Nepal & kadam \\
Chinese & yu-lu-tzu \\
Thailand & sabudam \\
Philippines & túbang-bákod, Tuba-tuba \\
Indonesia & jarak budeg \\
Côte d'Ivoire & bagani \\
Togo & kpoti \\
Senegal & tabanani \\
Angola & mupuluka \\
Nigeria & butuje \\
Tanzania & makaen \\
Mexico & piñoncillo \\
Costa Rica & coquillo, template \\
Puerto Rico & tártago \\
Brazil & mundubi-assu \\
Peru & piñol \\
Guatemala & Pinón \\
\hline
\end{tabular}

Sources: $[16,17]$.

known species. Dehgan and Webster [15] revised the subdivision made by Pax [18] and now distinguish two subgenera (Curcas and Jatropha) of the genus Jatropha, with 10 sections and 10 subsections to accommodate the Old and New World species. They postulated the physic nut $\{J$. curcas L. [sect. Curcas (Adans.) Griseb., subg. Curcas (Adans.) Pax]\} to be the most primitive form of the Jatropha genus. Species in other sections evolved from the physic nut or another ancestral form, with changes in growth habit and flower structures.

\subsubsection{Botanical description of J. curcas}

The physic nut, by definition, is a small perennial tree or large shrub, which can reach a height of three to $5 \mathrm{~m}$, but can attain a height of 8 or $10 \mathrm{~m}$ under favorable conditions. The plant shows articulated growth [11] straight trunk, thick branchlets with a soft wood and a life expectancy of up to 50 years [19]. Flowering occurs during the wet season [20] often with two flowering peaks, i.e. during summer and autumn. In the permanently humid regions, flowering occurs throughout the year [8]. The inflorescence is axillary paniculate polychasial cymes formed terminally on branches and are complex, possessing main and co-florescences with paracladia. Flowers are unisexual, monoeceious, greenish yellow colored in terminal long, peduncled paniculate cymes. Male flowers: calyx segments 5 , nearly equal, elliptic or obviate; corolla is campanulate, lobes 5, connate, hairy inside, exceeding the calyx, each lobe bear inside a gland at the base, stamens 10 in two series, outer five filaments free, inner five filaments connate, anthers dithecous erect, opening by longitudinal slit. Female flowers: sepals up to $18 \mathrm{~mm}$ long, persistent; calyx as in male, corolla 4 scarcely exceeding the calyx lobes united, villous inside; ovary 3-locular, ellipsoid, $1.5-2 \mathrm{~mm}$ in diameter, style bifid, ovules solitary in each cell. The inflorescences form a bunch of green trilocular ellipsoidal fruits yielding approximately 10 or more ovoid fruits [21]. The exocarp remains fleshy until the seeds are mature. Wiehr [22] and Droit [23] described the microscopical anatomy of the seeds in detail, while Singh [24] described that of fruits.

\subsection{Floral architecture and breeding system}

\subsubsection{Receptivity of male and female gametes}

J. curcas is monoecious, and produces male and female flowers in the same inflorescence. Microsporogenesis and male gametogenesis of $J$. curcas was studied by Liu et al. [25]. Male flowers of $J$. curcas have ten stamens, each of which bear four microsporangia. The development of the anther wall is of the dicotyledonous type, and is composed of an epidermis, endothecium, middle layer(s) and glandular tapetum. Chang-wei et al. [26] studied the pollen viability, stigma receptivity and reproductive features and found that, the life span of the male flower is about two days. Its pollen viability is relatively high $-9 \mathrm{~h}$ after blooming and gets low $33 \mathrm{~h}$ later - and pollen hardly has any viability after $48 \mathrm{~h}$. The life span of the female flower is about 5-12 days. The stigma receptivity is strong during $1 \mathrm{st}-4$ th day and begins to decline 5th day onwards and completely loses its receptivity on 9th day. There is no obvious secretion on the stigma. The higher proportion of green stigma indicates stronger receptivity. A few styles do not open after perianth's opening during rain and the stigma receptivity is quiet low. Normally, J. curcas shows protandry, while the female flowers open later, with $60 \%$ opening from the 3rd to the 5th day. There are still many unopen male flowers after all female flowers arer opened. This provides time for receptive stigma to get pollens from male flowers, and enhance the opportunity of reproductive success. In a few racemes, and the female flowers opened firstly shows a tendency to promote xenogamy (cross-pollination) and minimize geitonogamy (self-pollination) [26]. Dhillon et al. [27] observed flowering at the terminal end of branches after rainy season in India. However, some plants flower even in spring season (MarchApril). The average male to female (M/F) flower ratio was 20:1, which changes drastically $(108: 1)$ with the fall in temperature. Usual peak period of flowering varies from 3 to 20 days. Prakash et al. [28] observed variation in the $M / F$ ratio per inflorescence during the first year with average $\mathrm{M} / \mathrm{F}$ ratio of $25: 1$, and it reduced to $13: 1$ in the second year indicating a positive trend towards productivity. Bhattacharya et al. [29] examined the forenoon pattern of anthesis with subsequent pollen release with each male flower producing $1617 \pm 100$ pollen with Pollen:Ovule ratio as 539:1. The stigmas become receptive $2 \mathrm{~h}$ after anthesis, coinciding with nectar secretion and pollen presentation schedule. Each female flower $(4.54 \pm 0.82 \mu \mathrm{L})$ produces higher amount of nectar than male flower $(1.92 \pm 0.44 \mu \mathrm{L})$. Qing et al. [30] recorded 17 species of floral visitors among which 11 species were pollinators (Apis dorsata, A. florea, A. mellifera, Eumenes conica, Vespa sp.) with two floral visiting peaks at $10.00-12.00$ and $16.00-17.00 \mathrm{~h}$ everyday. Among the different insect visitors Apis spp. were the most frequent. Sucrose level influence flower-visit duration, pollen removal and deposition on stigmas by honeybees [29]. Period of fruit development and maturity ranged from 55 to 61 days from date of first fruit initiation [27].

\subsubsection{Nature of pollination}

Breeding system plays a critical role in deciding the route of plant evolution and hence breeding [31]. There are three kinds of mechanisms in plant breeding systems; geitonogamy, xenogamy and apomixsis [32]. In spite of the common existence of geitonogamy, the tendency to promote xenogamy is still universally significant way of evolution in angiosperms [33,34]. Plants have various adaptive ways to guarantee xenogamy, such as dioecism (separation between male and female sexual plants), dichogamy (timing separation of male and female sexual functions), opposite styles, styles of different lengths and self-incompatibility [35,36]. The results of breeding system indicated $32.9 \%$ fruit setting under selfing and $89.7 \%$ under natural pollination in jatropha. The high fruit setting under open pollination revealed that the plant is capable of 
producing fruits through selfing and cross-pollination. Such a breeding system represents facultative cross-pollination [27]. However the fruit sets of artificial self-pollination, artificial crosspollination and natural cross-pollination were 87.93\%, 86.66\% and $76.42 \%$, respectively, which indicated that $J$. curcas was selfcompatible and tended to cross-pollinate [30]. The ability to selfpollinate through geitonogamy is considered to be adaptive for $J$. curcas for colonization [20]. Fifty percent of female flowers set fruit with $53 \%$ fecundity rate, $32 \%$ apomixis rate and $2: 3$ seed-ovule ratio [29]. Chang-wei et al. [37] and Abdelgadir et al. [38] suggest that fruit production can be boosted by manipulating biological processes of pollination and growth.

\section{Genetic improvement}

Very little is known about Jatropha genome. Chromosomes are of very small size (bivalent length $1-3.67 \mu \mathrm{m}$ ) with most species having $2 n=22$ and base number of $x=11$ [39]. It is attractive candidate for genome sequencing with genome size (1C) to be $416 \mathrm{Mbp}$ [40]. J. curcas is an introduced plant to many countries of Asia, Africa and Latin America and there have not been many systematic efforts for improvement of this crop. Improved varieties with desirable traits for specific growing conditions are not available, which makes growing jatropha a risky business [13]. The objectives for genetic upgradation of the crop should aim at more number of female flowers or pistillate plants, high seed yield with high oil content, early maturity, resistance to pests and diseases, drought tolerance/resistance, reduced plant height and high natural ramification of branches. In addition to these targets, genetic improvement in general characteristics and methyl ester composition to make it more suitable for bio-diesel production as compared to Pongamia pinnata (Table 2) are also important. Correlation studies conducted by Mukta et al. [45] in P. pinnata has indicated that, with increase in cetane number (ability of fuel to ignite), iodine number decreases, which means un-saturation decreases. Since iodine number is under strong genetic control (unpublished data), using genotype having low iodine number will prelude to efficient bio-diesel yielders with high cetane number. Sujatha [46] and Sujatha et al. [47] reported that genetic improvement and domestication of $J$. curcas should follow the same course as that of castor (Ricinus communis L.) belongs to the same family. Castor has been improved from a perennial wild to annual domesticate, having short internodes with varying flower sexuality ratios from completely pistillate to predominantly male types [48]. The success is due to the use of mutation techniques, selection of germplasm and identification of pistillate variants [49]. J. curcas can be improved through assessment of variation in wild source and selection of superior/elite genotypes and application of mutation, alien gene transfer through inter-specific hybridization and biotechnological interventions to bring the change in the desired traits. Enhancement of productivity can be achieved through development of pistillate plants and/or to identify divergent parents, which can later be exploited by heterosis. Development of pistillate plants through mutation and inter-specific hybridization techniques is time consuming. Meanwhile, physiological manipulation of sexuality, applying gametocides to enhance the $M / F$ ratio and altering the expression levels of enzymes in the triacylglycerol biosynthetic (Kennedy) pathway [50] may also be considered to increase yield.

\subsection{Germplasm collection, characterization and availability}

The key for success of any genetic improvement programme lies in the availability of genetic variability for desired traits [8]. Genetic resource through global exploration, introduction, characterization and evaluation will provide strong base for development of

Table 2

Oil and methyl ester composition and general characteristics of Jatropha curcas and Pongamia pinnata.

\begin{tabular}{|c|c|c|c|c|c|}
\hline & & Jatropha curcas & \multicolumn{2}{|c|}{ Pongamia pinnata } & \multirow[t]{2}{*}{ EN 14214:2003 } \\
\hline & Oil & Methyl esters & Oil & Methyl esters & \\
\hline \multicolumn{6}{|l|}{ Major fuel properties } \\
\hline Density $\left(\mathrm{g} \mathrm{cm}^{-3}\right)$ & 0.916 & 0.875 & 0.909 & 0.876 & $0.860-0.900$ \\
\hline Flashpoint $\left({ }^{\circ} \mathrm{C}\right)$ & 235 & 186 & 232 & 183 & $>120$ \\
\hline Cetane number & 46.3 & $57-62$ & 54.0 & 55.0 & $>51$ \\
\hline Carbon Residue (\%) & 0.38 & 0.18 & 1.51 & - & $<0.3$ \\
\hline Sulfur content (\%) & $0-0.13$ & 0.0036 & 0.007 & - & $<0.01$ \\
\hline Calorific value (MJ kg-1) & 39.63 & 39.65 & - & 37.12 & - \\
\hline Acid Number ( $\mathrm{mg} \mathrm{KOH} \mathrm{g}^{-1}$ ) & 3.71 & 0.27 & 5.91 & 0.42 & $<0.5$ \\
\hline Iodine number ( $\mathrm{mg}$ iodine $\mathrm{g}^{-1}$ ) & 101.7 & 95-106 & 89 & 91 & $<120$ \\
\hline Saponification number $\left(\mathrm{mg} \mathrm{g}^{-1}\right)$ & 195 & 202.6 & 185 & 187 & - \\
\hline Free glycerol (\%) & - & $0.015-0.030$ & - & 0.015 & $<0.02$ \\
\hline Total glycerol (\%) & - & $0.088-0.100$ & - & 0.797 & $<0.25$ \\
\hline Viscosity at $40^{\circ} \mathrm{C}\left(\mathrm{mm}^{2} / \mathrm{s}\right)$ & 40.06 & 4.20 & 41.06 & 4.66 & $3.5-5.0$ \\
\hline General characteristics & \multicolumn{2}{|l|}{ Jatropha curcas } & \multicolumn{3}{|c|}{ Pongamia pinnata } \\
\hline Ecosystem & \multicolumn{2}{|c|}{ Arid to semi-arid, up to $500 \mathrm{~m}$ altitude } & \multicolumn{3}{|c|}{ Semi-arid to sub-humid, up to $1200 \mathrm{~m}$ altitude } \\
\hline Rainfall & \multicolumn{2}{|c|}{ Low to medium up to $1200 \mathrm{~mm}$} & \multicolumn{3}{|c|}{ Medium to high up to $2500 \mathrm{~mm}$} \\
\hline Soil & \multicolumn{2}{|c|}{ Well drained soils } & \multicolumn{3}{|c|}{ Tolerant to water logging, saline and alkaline soils } \\
\hline Nitrogen fixation & \multicolumn{2}{|l|}{ Non fixer } & \multicolumn{3}{|c|}{$\mathrm{N}_{2}-$ fixing } \\
\hline Plant suitability & \multicolumn{2}{|c|}{$\begin{array}{l}\text { Wastelands, degraded lands, live fence for arable lands, } \\
\text { green capping of bunds, shallow soils }\end{array}$} & \multicolumn{3}{|c|}{$\begin{array}{l}\text { Field boundary, river and stream banks stabilization, wastelands, } \\
\text { tank foreshore }\end{array}$} \\
\hline Plant habit & \multicolumn{2}{|c|}{ Mostly bush, can be trained as small tree } & \multicolumn{3}{|c|}{$\begin{array}{l}\text { Tree can be managed as bush by repeated pruning but will affect } \\
\text { yield }\end{array}$} \\
\hline Leaves & \multicolumn{2}{|c|}{ Not palatable by livestock } & \multicolumn{3}{|c|}{ Not palatable by livestock, used as green leaf mulch } \\
\hline Gestation period & \multicolumn{2}{|l|}{ Short, 3rd year } & \multicolumn{3}{|c|}{ Long, 7th year } \\
\hline Yield & \multicolumn{2}{|l|}{$1.0 \mathrm{~kg} /$ plant } & \multicolumn{3}{|c|}{$10-200 \mathrm{~kg} /$ tree } \\
\hline Oil content & \multicolumn{2}{|l|}{$27-38 \%$ in seed } & \multicolumn{3}{|c|}{$27-39 \%$ in kernel } \\
\hline Protein & \multicolumn{2}{|l|}{$38 \%$} & \multicolumn{3}{|c|}{$30-40 \%$} \\
\hline Fire wood & \multicolumn{2}{|l|}{ Not useful } & \multicolumn{3}{|c|}{ Good as firewood, high calorific value $4600 \mathrm{k} \mathrm{cal} / \mathrm{kg}$} \\
\hline
\end{tabular}

Sources: [19,41-44,58]. 
elite varieties by various improvement methods. Comprehensive work on collection, characterization and evaluation of germplasm for growth, morphology, seed characteristics and yield traits is still in its infancy. The fact that jatropha has adapted itself to a wide range of edaphic and ecological conditions suggest that there exists considerable amount of genetic variability to be exploited for potential realization [51]. Species and provenance trials contribute fundamental information for further breeding and genetic improvement [52]. Systematic provenance trials have not yet been carried out with the physicnut to the necessary extent, and material from the centre of origin has not been sufficiently screened. The genetic background of the physic nut grown in Africa and Asia is unclear. Certain provenances may differ relatively from others if cultivated at different sites, which is due to $\mathrm{G} \times \mathrm{E}$ interaction $[53,54]$. Priority should be given to assess intra- and inter-accessional variability in the available germplasm, selection of pure lines and then multiplication. Existence of natural hybrid complexes is reported in the genus Jatropha, such as, J. curcas-canascens complex in Mexico [55], J. integerrima-hastata complex in Cuba and West Indian islands [18] and J. curcas-gossypifolia (J. tanjorensis) in India [56]. Hence, germplasm exhibiting gross morphological differences should be subjected for pollen studies and lines with pollen abnormality or poor seed set should be investigated in detail before drawing conclusions about the distinctness. Makkar et al. [57] reported large variations in contents of crude protein, crude fat, neutral detergent fiber and ash on 18 different provenances of jatropha from countries in West and East Africa, the Americas and Asia. Wani et al. [58] recorded variation in Indian accessions for oil content (27.8-38.4\%) and 100 seed weight (44-77 g). Kaushik et al. [59] explored the variability in Haryana-India accessions to find wide variation in 100 seed weight (49-69 g) and oil content (28-39\%). Similarly Rao et al. [51] found wide variation in 100 seed weight (57-79 g) and oil content (30-37\%) for Andhra Pradesh, India, accessions.

\subsection{Genetic studies of traits}

Although selection based on seed characters would simplify the task, there still exist several limitations and doubts in these selected plants because of season and time bound expression of genes of interest. Knowledge of genetic variation in branching pattern, $\mathrm{M} / \mathrm{F}$ flower ratio, pest resistance, drought resistance and yield attributes in wild jatropha germplasm can be of great potential in improvement programs. This is particularly important in selection of genotypes with more oil content and yield. Hence a large scale collection of germplasm from selected plus trees, their conservation and the evaluation program of various jatropha accessions is essential to understand patterns of variability. Estimation of correlation among characters, broad sense heritability and genetic advance will be useful to determine the extent to which improvement is possible through selection.

Kaushik et al. [59] recorded coefficients of variance between 24 Haryana provenances, India, which envisaged that environment has comparatively low influence on the seed traits and oil content. High broad sense heritability and high genetic advance for oil content in jatropha indicates potentiality of test material for further improvement through selection [51,59]. Positive significant association was observed between seed weight and oil content [59]. Rao et al. [51] evaluated genetic association and variability in seed and growth characters and found that M/F ratio had the highest positive direct relationship with seed yield (0.789), followed by number of branches (0.612) and number of days from fruiting to maturity (0.431) with high heritability for these traits. In another study using ten sources from central India, seed oil content was significantly correlated with seed weight (0.792), stem diameter (0.836) and total leaf area (0.883) [60]. Observation on influence of regional climate [61] and altitudinal ranges [62] on seed oil content variation are recorded.

\subsection{Phenotypic diversity studies}

Analysis of phenotypic diversity in germplasm collections can facilitate reliable classification of accessions and its identification with future utility for specific breeding purposes. There are very few studies on phenotypic diversity involving a limited number of germplasm and their suggested use in hybridization. Sunil et al. [63] developed a methodology for identification of superior lines by assessing the phenotypic traits of plants recorded in situ. Further, they generated grid maps for the distribution pattern based on plant height, number of primary branches, collar length, number of fruits per cluster and oil content using Geographic Information System (GIS) to find the potential area for germplasm with high oil content based on rarefaction method of DIVA-GIS [64]. Heller [65] tested 13 provenances in multilocation field trials in 1987 and 1988 in two countries of the Sahel region: Senegal and Cape Verde. Significant differences in the vegetative development except leaf shape were detected among the various provenances at all locations. Kaushik et al. [59] studied divergence among 24 accessions using non-hierarchical Euclidian cluster analysis for seed traits in jatropha and suggested that the crossing between accessions of clusters IV and VI will result in wide spectrum of variability in subsequent generations. Gohil and Pandya [66] analysed diversity based on phenotypic traits of nine jatropha genotypes and suggested that for varietal improvement, hybridization among the genotypes of divergent clusters (clusters - III, IV and V) may be done in order to obtain better results in terms of variability and diversity. Rao et al. [51] observed four clusters with phylogeographic patterns of genetic diversity among 32 high yielding candidate plus trees of $J$. curcas for seed traits.

\subsection{Selection and genetic improvement}

The core activities of genetic improvement programs are selection and breeding. J. curcas is an often cross-pollinated crop and hence following genetic improvement methods can be applied to exploit genetic variation in jatropha: (i) mass selection; (ii) recurrent selection; (iii) mutation breeding; (iv) heterosis breeding and (v) inter-specific hybridization.

\subsubsection{Mass selection}

Mass selection is the simplest, easiest and oldest method of selection where individual superior plants are selected based on their phenotypic performance and bulk seed is used to produce the next generation for genetic improvement (Fig. 1). To make genetic gains by this technique, there must be a positive offspring-parent regression which in turn depends greatly upon the magnitude of the environmental effects in the parental population. However, mass selection has a major drawback of lack of control of the pollen source, confusing effect of the environment and reduced population size leading to inbreeding depression. But these disadvantages can be taken care by de-tasselling/roughing of inferiors and crossing with of bulked pollens of superior plants. Mishra [67] devised a paired comparison method for selecting plus phenotypes of $J$. curcas trees with due importance to seed and oil yields. A global effort to evaluate the genetic variability in J. curcas was initiated by Montes et al. [68] using 225 accessions collected from 30 countries in Asia, Africa and Latin America and found low genetic variation in African and Indian accessions and high genetic variation in Guatemalan and other Latin American accessions. This is in support of earlier phenotypic and genotypic evaluation studied by Basha and Sujatha [69] on accessions of India. In India, Jatropha germplasm including a few wild species have been introduced 


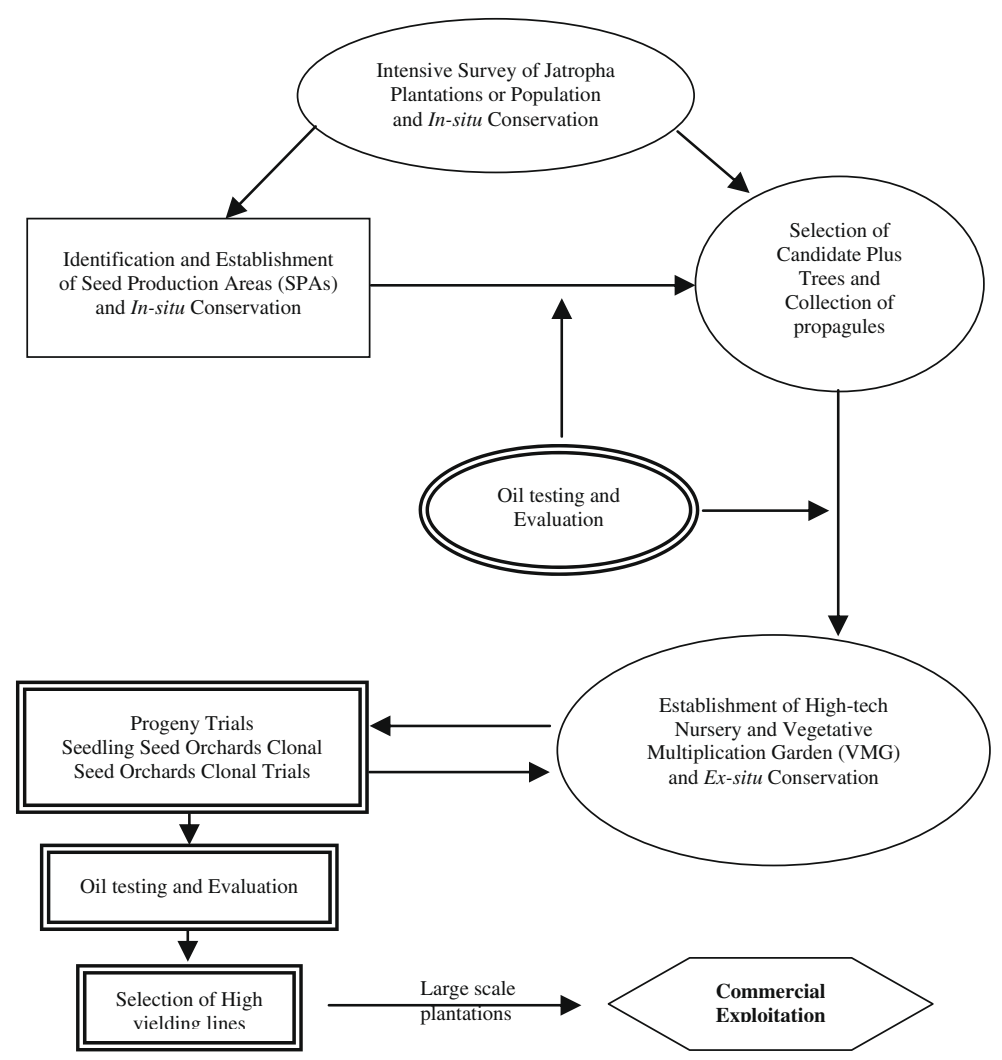

Fig. 1. Approach for genetic improvement of Jatropha curcas L.

from Brazil, Mali, Australia, Ghana, Nigeria, Mexico, Nicaragua and Nepal but these include only one or two accessions. Wild J. curcas germplasm is available in tropical America, Africa and South Asia $[8,55]$. This indicates the need for widening the genetic base of $J$. curcas germplasm as new source of genetic variation.

In India, the National Oilseeds and Vegetable Oils Development (NOVOD) Board (Ministry of Agriculture, Government of India) has identified 1855 candidate plus trees (CPTs) of jatropha and has over five thousand accessions collected with a network of 40 institutions. The oil content varies from $26.0 \%$ to $42.7 \%$ [70]. Department of Biotechnology (DBT), Government of India, launched micro-mission on production of quality planting material with $30-40 \%$ oil and 3-5 tonnes/ha seed yield, under this mission 1500 accessions have been collected [71]. Kaushik et al. [72] analysed one thousand samples of jatropha seeds representing twelve states of India for oil content and kernel seed coat ratio and reported that collection from Uttaranchal recorded highest percentage of high oil yielding plants (73\%). Most of the J. curcas varieties spread all over the world viz. the variety - Cape Verde, variety from Nicaragua and a non-toxic variety from Mexico are developed from selections made in the natural populations $[8,12]$. The first variety, SDAUJ I (Chatrapati), has been identified for commercial cultivation in the semi-arid and arid regions of Gujarat and Rajasthan in India (http://www.icar.org.in/pr/ 10052006.htm). Indian Council of Agricultural Research (ICAR) launched network project in which, 28 seed sources were identified as the best among 496 seed sources [73].

\subsubsection{Recurrent selection}

Recurrent selection schemes were devised in relation to heterosis breeding and may be useful in improving specific combining ability in jatropha by overcome all deficiencies of mass selection. The idea was to ensure the isolation of superior inbred from the populations subjected to recurrent selection for their ultimate utilization in the production of hybrid and synthetic varieties. Theoretically, recurrent selection is a breeding procedure for increasing the frequency of desirable genes within a population while maintaining sufficient variability for continued selection. Jatropha being a cross-pollinated plant, 15 open-pollinated varieties have been developed using mass selection and recurrent selection methods in India and are under testing in the National Trials. After obtaining the required data on seed yield, oil content and oil quality, disease and insect pest resistance, the best performing genotypes will be released as new varieties of jatropha by adopting the standard procedure [70]. The importance of such considerations to tree breeding programs is obvious.

\subsubsection{Mutation breeding}

Mutation is a sudden heritable change in a character as a result of change in gene or chromosome(s). Mutations occur in natural populations at low rate and are generally recessive and random. Mutation in tree crops is considered attractive because of lacunae in conventional breeding like time consuming, unpredictable results, long juvenile phase, high heterozygosity and fear of loss of the unique genotype. However, mutation breeding is not directed and long drawn but is one of the available options for genetic improvement of $J$. curcas with modest levels of variability. Mutation breeding studies in J. curcas carried out in Thailand using fast neutrons and isolated dwarf or early flowering mutants from the $\mathrm{M}_{3}$ generation, but the potential productivity of these variants under intensive cultivation conditions was not proved [74]. Dwimahyani and Ishak [75] used induced mutations in J. curcas for improvement of agronomic characters with irradiation dose of $10 \mathrm{~Gy}$ and identified mutant plants with early maturity, 100 seeds weight (30\% over control) and better branch growth. In India, mutation breeding using chemical and physical mutagens has been 
initiated to create genetic variation for various traits and developed mutants are being characterized using DNA markers [70]. Mutation studies undertaken at National Botanical Research Institute (NBRI), Lucknow, India has led to induction of cotyledonary variabilities in J. curcas [76]. The mutants themselves may not be suitable for direct release, but they do provide the necessary alleles for developing superior cultivars with desirable traits.

\subsubsection{Heterosis breeding}

The exploitation of heterosis is a common objective in plant breeding [77]. Heterosis in tree growth is evident in many hybrids and perhaps best illustrated in studies of Eucalyptus and Populus (the genus of poplars and aspens). J. curcas as a facultative crosspollinated crop shows heterosis, particularly when inbred lines are used as parent. Based on the earlier experience from other cross-fertilized crops, it appears that in jatropha application of heterosis breeding could justify hybrid variety production. Seed and oil yield can be genetically enhanced through simple selection of superior germplasm and release as cultivars. In addition, hybrid cultivars could be bred to use the heterosis effect. Literature on jatropha improvement through heterosis are scarce. Inter-specific hybrids utilizing $J$. curcas as the female parent and J. integerrima as the male parent indicated that the $\mathrm{F}_{1}$ hybrids had a wide range of variation for vegetative, flowering and fruiting characters [78].

\subsubsection{Inter-specific hybridization}

The early views that inter-specific hybridization would be a panacea for all tree improvement problems has largely been dispelled. Heterosis in hybrids, far from being a common phenomenon, is rare. Probably the more promising, and most useful contribution of inter-specific hybridization is in transferring desirable genes from one species to another, e.g. Populus, Eucalyptus. As any forest tree, J. curcas breeding is a time-consuming process due to perenniality. Since, most of the Jatropha species are insensitive to photoperiod and bear flowers continuously, selection and generation advancement can be accomplished without much time lapse. Other added advantage is the propensity of $J$. curcas towards interspecific hybridization, supported by propagation both through seeds and vegetative propagule, which helps in rapid multiplication and acceleration of the breeding programs. Usually breeding objectives in J. curcas depend on solving specific problems of cultivation and intended application of economic output (seed and oil). Components that contribute to physic nut seed and oil yield per hectare are: more number of pistillate flowers per inflorescence and subsequent number of capsules per shrub, 1000-seed weight, oil content of seeds (\%) and plants per hectare. As the maximum number of seeds per capsule is limited and the agronomic factor of planting density does not offer much flexibility for increasing yields, selection should focus on the other yield contributing components.

Dehgan and Webster [15] regarded J. curcas as the most primitive member of the genus because of its ability to interbreed with species of both the subgenera. Evolution of the genus Jatropha led to specialization of vegetative structures, culminating in a facultative annual growth habit in section Jatropha and in rhizomatoussub-shrub habit in section Mozzina. Studies on phylogenetic significance of inter-specific hybridization in jatropha by Dehgan [79] confining to identification of crossability barriers and morphological characterization revealed that all $\mathrm{F}_{1}$ hybrids, except $J$. curcas $\mathrm{x} J$. multifida, were more vigorous than the parental species. The species that could be crossed unilaterally with $J$. curcas as female parent include J. macrorhiza, J. capensis, J. cathartica, J. multifida, J. podagrica, $J$. cordata, and $J$. cinerea. Inter-specific hybridization has immense scope for improving the genetic architecture and agronomic attributes of $J$. curcas [46]. Initial success in obtaining inter-specific $\mathrm{F}_{1}$ and back cross (BC1) plants with low phorbol es- ters and improved agronomic traits in J. curcas and further BC populations leading to varieties with targeted traits has been reported (http://precedings.nature.com/documents/2782/version/1). To increase genetic diversity and add new alleles, inter-specific crosspollination was attempted between $J$. curcas and other Jatropha species by Parthiban et al. [80] to develop new hybrids with higher yield potential and resistance to diseases. Among all the crosses, the cross between J. curcas and J. integerrima produced successful hybrids with more seed set, while the other crosses failed to produce seeds due to existence of crossability barriers. In contrary Basha and Sujatha [81] produced artificial hybrids between J. curcas and all Jatropha species used in the study with the exception of $J$. podagrica without any crossability barriers. Evaluation of backcross inter-specific derivatives of cross involving J. curcas and J. integerrima indicate scope for prebreeding and genetic enhancement of $J$. curcas through inter-specific hybridization [80-83].

J. curcas has been considered to be less attacked by insect pests and diseases are merely based on solitary tree observation. The potential value of related species in genetic enhancement of resistance of $J$. curcas to various biotic stresses is of immense importance. Blue bugs and green stink bug will be sucking on fruits (Scutellera nobilis) and capsule-borer (Pempelia morosalis) will damage the fruits. However, incidence of pests (scutellarid bug, inflorescence and capsule-borer, blister miner (Stomphastis thraustica), semi-looper (Achaea janata), flower beetle (Oxycetonia versicolor), defoliator and pod borer and diseases (collar rot, black rot, leaf spots, root rot, damping off and Cassava mosaic virus) is frequently reported and particularly when the crop is raised as plantations. Screening of five Jatropha species against foliage feeders revealed resistance of $J$. integerrima in terms of maximum mortality, low larval weight gain with or without pupation [84]. Drought, soil salinity and water logging are major abiotic stresses in areas of jatropha cultivation. Due to complex nature of these stresses and lack of appropriate screening technologies no systematic breeding program has undertaken. However, adaptability improvement of $J$. curcas to problematic sites can be achieved through grafting of $J$. curcas scions with J. gossypifolia stock since it thrives well on saline soils [46].

\subsection{Breeding programs}

\subsubsection{Global perspective}

At global level, J. curcas evaluation, breeding and propagation programme is carried from 2006 to 2010 by Wageningen University and Research Centre, Plant Research International, the Netherlands (www.jatropha.wur.nl). Efforts on screening of different genotypes and breeding has begun in order to produce high yielding plants at Lao Institute of Renewable Energy (LIRE) - Lao PDR (http:// www.lao-ire.org/j1.4-jatropha-breeding-experiments.html). Surfactant and Bio-energy Resource Centre (SBRC) in Bogor has started jatropha breeding activities by developing germplasm collection farm with about 200 accessions from various areas in Indonesia and overseas which will be used to engineer plants with preferred traits. Characterization of physical and morphological properties and genetic characterization for further variety engineering are in progress (http://id.sbrc-ipb.com). The Centro Hispaniola de Investigación en Bioenergias y Agricultura Sostenible (CHIBAS) - bi-national (Haiti and Dominican Republic) based in the Dominican Republic is improving the stocks of jatropha by establishing an efficient jatropha germplasm repository (live collection) and the development and release of germplasm (new improved varieties) adapted to the new needs for oil and bio-diesel production (www.chibas-bio-energy.org/en-web-jatropha.pdf). The Agricultural Research Trust (ART), Zimbabwe has developed non-toxic varieties of $J$. curcas, which would make the seed cake following 
oil extraction suitable as animal feed without its detoxification (http://precedings.nature.com/documents/2658/version/1).

\subsubsection{Indian perspective}

National Oilseeds and Vegetable Oils Development (NOVOD) Board (Ministry of Agriculture, Government of India) has over five thousand accessions collected with a network of 40 institutions and found 39 hybrid clones which showed wide variation in their morphological traits. Reproductive biological studies were undertaken in all hybrid clones. The preliminary results of this study showed that four species viz. J. curcas, J. gossyfolia, J. multifida and J. podagrica were found cross in-compatible to each other. Apomictic nature (fruit development without fertilization) of $J$. podagrica and $J$. multifida was detected by crossing five different species of Jatropha in all possible combinations and concluded not to use these two species as female parents, but their pollens from male flowers can be used for pollinating the other species. However, the crosses were successful when J. multifida (50\% oil content) was used as male ( $\hat{\jmath}$ ) and J. curcas (23-38\%) as female ( $(+)$ parent. The crossability barriers between these two species are weak and the cross combination aids in enhancement of oil content. A strong reciprocal compatibility was also found between $J$. curcas and $J$. integerrima and successful hybrid plants were developed [70].

\subsection{Biotechnological intervention}

The small genome size, chromosome number, ease of vegetative manipulation [85] and transformation [86] are favorable features for the use of biotechnological tools for $J$. curcas improvement. The potential benefit of biotechnological intervention in jatropha improvement is possibility of gaining time in certain improvement process. Conventional propagation of $J$. curcas is beset with problems of poor seed viability, low germination, scanty and delayed rooting of seedlings and vegetative cuttings $[8,87]$. Plants propagated by cuttings show a lower longevity and possess a lower drought and disease resistance than those propagated by seeds [8]. Plants produced from cuttings do not produce true taproots (hence are less drought tolerant); rather, they produce pseudo-taproots that may penetrate only one-half to two-thirds the depth of the soil compared to taproots produced on seed grown plants [8]. Added to this, a large amount of quality planting material is required for future use. Considering its enormous potential, in depth studies need to be made for use of biotechnological tools in jatropha genetic improvement.

\subsubsection{Micro-propagation application}

The tissue culture protocols serve as a prelude for genetic improvement through biotechnological tools. Micro-propagation of $J$. curcas has been reported by various authors [85,88], using different tissues except nodal explants from the field grown plants. Regardless of the species and explant used, shoot regeneration occurred on medium supplemented with benzyladenine and indolebutyric acid but the concentration of growth regulators varied with the genotype and explant. Also in all of the cases the multiplication rate was low for application. These studies revealed that the scope for improvement of $J$. curcas through somatic hybridization [89] in inter-specific crosses limited by crossability barriers. Somatic embryogenesis not only helps to obtain a large number of plants year round, but also can act as a powerful tool for genetic improvement of any plant species because of its single cell origin [90].

\subsubsection{Molecular markers in genetic diversity analysis and selection}

The development and use of molecular markers for the detection and exploitation of DNA polymorphism is one of the significant achievements in the field of molecular genetics which accelerate breeding by establishment of molecular fingerprints for distinct and most divergent accessions using diversity analysis [91]. DNA based markers such as Random Amplified Polymorphism DNA (RAPD), Enhanced Random Amplified Polymorphism DNA (ERAPD), Simple Sequence RepeatSimple Sequence Repeat (Simple Sequence Repeat), Sequence Characterized Amplified Region (SCAR), Amplified Fragment Length Polymorphism (AFLP) and Inter-Simple Sequence Repeat (ISSR) can be used to assist breeding through Marker Assisted Selection (MAS) to select prospective varieties from seedling stage. Microsatellite markers are available for a few Euphorbiaceae members and are being developed for castor [92,93; http://castorbean.tigr.org/]. As the developmental costs for microsatellite markers are high, cross-taxa utility of molecular markers from hevea and cassava could be assessed as done in other plant species [94]. Majority of the studies are confined to characterization of accessions available in India (Table 3) except Basha and Sujatha [69] having one non-toxic accession from Mexico, Montes et al. [68] having accessions from 30 countries and Sun et al. [95] having accessions from south China. Regardless of the number of accessions used, the robustness of the primer and number of marker data points, all accessions from India clustered together. In general, diversity analysis with local germplasm revealed a narrow genetic base in India $[69,97]$ and south China [95], indicating the need for widening the genetic base of $J$. curcas through introduction of accessions with broader geographical background and creation of variation through mutation and hybridization techniques. In contrary to the above studies, AFLPbased molecular characterization of $J$. curcas accessions from Andhra Pradesh were found diverse as these were scattered in different groups, showed occurrence of higher number of unique/rare fragments and had greater variation in percentage oil content [102]. However, careful understanding of the phylogeny and use of adequate number of molecular markers are essential prerequisites for drawing valid inferences about the genetic affinities [47]. However, Basha and Sujatha [81] characterized Jatropha species occurring in India using nuclear and organelle specific primers revealed high inter-specific genetic variation (98.5\% polymorphism). Further characterization of both natural and artificially produced hybrids using chloroplast specific markers revealed maternal inheritance of the markers [81]. In support, genetic variation studies using RAPD, AFLP and combinatorial tubulin based polymorphism (CTBP) indicating higher possibilities of improving $J$. curcas by inter-specific breeding (http://precedings.nature.com/documents/2782/version/1). Hence, molecular diversity estimates combined with the datasets on other agronomic traits will be very useful for selecting the appropriate accessions.

Table 3

Characterization of accessions using molecular markers.

\begin{tabular}{llcl}
\hline Species/accessions & Primers & Number & References \\
\hline 142 & AFLP & - & DBTIndia [96] \\
5 & RAPD & 18 & GaneshRam et al. [97] \\
22 & RAPD & 7 & Ranade et al. [98] \\
& DAMD & 4 & \\
13 & RAPD & 20 & Gupta et al. [99] \\
& ISSR & 14 & \\
7 & RAPD & 52 & Pamidiamarri et al. [100] \\
& AFLP & 27 & \\
20 & RAPD & - & Reddy et al. [101] \\
& AFLP & - & \\
43 & RAPD & 400 & Basha and Sujatha [69] \\
& ISSR & 100 & \\
58 & AFLP & - & Montes et al. [68] \\
& SSR & 30 & Sun et al. [95] \\
\hline
\end{tabular}




\subsubsection{Genetic engineering}

Genetic engineering through transformation has been widely used to obtain transgenic plants through some stages in molecular and cellular biological techniques is another valuable method for the development of $J$. curcas variety. Recently a new full length cDNA of stearoyl-acyl carrier protein desaturase was obtained by RT-PCR and RACE techniques from developing seeds of Jatropha and the gene was functionally expressed in Escherichia coli [103]. It is an important enzyme for fatty acid biosynthesis in higher plants and also plays an important role in determining the ratio of saturated fatty acid to unsaturated fatty acids in plants [104]. For understanding the molecular mechanism of salt and drought tolerance, a new full length cDNA encoding aquaporin (JcPIP2) was isolated from seedling of $J$. curcas, the abundance of JcPIP2 was induced by heavy drought stress and it plays an important role in rapid growth of Jatropha under dry conditions [105]. Zhang et al. [106] reported a novel betaine aldehyde dehydrogenase gene (BADH) named JcBD1 (cloned by RT-PCR and RACE techniques from $J$. curcas) is increasingly expressed in leaves undergoing environmental stress like drought (30\% PEG), heat $\left(50^{\circ} \mathrm{C}\right)$ and salt $(300 \mathrm{mM} \mathrm{NaCl})$. The JcBD1 protien was functionally expressed in Escherichia coli and conferred its resistance to abiotic stresses like salt. Li et al. [107] established highly efficient genetic transformation procedure for J. curcas for the first time via Agrobacterium tumefaciens infection of cotyledon disc explants. This helps in genetic modification and subsequent in vitro multiplication of cultivars for various uses. Further, the technology helps in better understanding and subsequent improvement of the oil biosynthesis pathway, which could have positive implications on reducing the world's dependence on fossil reserves.

\subsubsection{Jatropha genome project}

Synthetic Genomics Inc. (SGI) and Asiatic Centre for Genome Technology (ACGT) completed jatropha genome project. The sequencing of the genome, using both traditional sanger sequencing and next generation sequencing, has revealed that the jatropha genome is approximately 400 million base pairs in size, similar to the size of the rice genome. Annotation of genome to identify genes of interest helps in discovering genetic variation using marker-assisted breeding and provide information on factors controlling oil synthesis, maximizing yield, biotic and abiotic stress tolerance and low-curcin variants (http://greenbio.checkbiotech.org/news/ first_jatropha_genome_completed_synthetic_genomics_inc_and_ asiati 511 c_centre_genome_tech).

\section{Future strategy for crop improvement}

$J$. curcas is still in its infancy with respect to genetic improvement for increasing seed and oil yield per unit area. Genetic improvement activities so far involved only collection and selection in local germplasm and hence initiatives to evaluate global germplasm is necessary, to study pattern of diversity for various traits. Genetic improvement using conventional breeding approaches has to be initiated at more places and integrated with latest biotechnological techniques for reducing time and increasing efficiency of breeding. Potential of the new varieties developed has to be further tested for their performance, through multilocation trials. Development of techniques such as, somoclonal variants, mutations, doubled haploids, and gene transfer which support plant breeding activities should be emphasized. Similar to other crops, heritability of seed traits is the most common predictor of genetic gains for different breeding methods in jatropha. Application of information from jatropha genome project can be used in marker-assisted breeding to accelerate and complement conventional breeding. Genetic transformation and gene transfer is particularly important for traits for which variability is unavailable in the cultivated species.

\section{Conclusions}

J. curcas has spread beyond its original distribution because of its hardiness, easy propagation, drought endurance, high oil content, low seed cost, short gestation period, rapid growth, adoption to wide agro-climatic condition, bushy/shruby nature and multiple uses of different plant parts. Although jatropha is well known for having wide adaptability and plethora of uses, the full potential of $J$. curcas is far from being realized because of several reasons. Improved varieties with desirable traits for specific growing conditions are not available, which makes growing jatropha a risky business. Apart from agronomic, socioeconomic and institutional constraints, planned crop improvement programs are lacking globally. Hence, J. curcas can be improved through assessment of variation in wild sources and selection of superior/elite genotypes and application of mutation, alien gene transfer through inter-specific hybridization and biotechnological interventions to bring the change in the desired traits. Enhancement of productivity can be achieved through development of pistillate plants and exploiting by heterosis.

\section{References}

[1] Parikh J. Growing our own oils. Biofuels India 2005;3(3):7.

[2] OECD-FAO. Agricultural outlook 2008-2017. 2008; <www.oecd.org/ publishing/corrigenda>.

[3] Shukla SK. Experiences of Chattisgarh biofuel development authority. Biofuels India 2005;3(4):12-3.

[4] Wani SP, Sreedevi TK, Reddy BVS. Biofuels: status, issues and approaches for harnessing the potential. Hyderabad, India; 2006. <www.indianjournals.com/ ijor.aspx? target=ijor:in \&volume $=3$ and $4 \&$ issue $=4$ and $1 \&$ article $=004>$

[5] Hegde DM. 2003. Tree oilseeds for effective utilization of wastelands. In: Compendium of lecture notes of winter school on wasteland development in Rainfed areas, Central Research Institute for Dryland Agriculture, September 1-30, Hyderabad, India; 2003. p. 111-9.

[6] Reddy BVS, Ramesh S, Ashok kumar A, Wani SP, Ortiz R, Ceballos H, et al. Biofuel crops research for energy security and rural development in developing countries. Bioenergy Res 2008;1:248-58.

[7] Tiwari AK, Kumar A, Raheman H. Biodiesel production from Jatropha (Jatropha curcas) with high free fatty acids: an optimized process. Biomass Bioenergy 2007;31:569-75.

[8] Heller J. Physic nut Jatropha curc as L. Promoting the conservation and use of underutilized and neglected crops. Institute of Plant Genetic and Crop Plant Research, Gatersleben/International Plant Genetic Resource Institute, Rome, Italy 1996. <http://www.ipgri.cgiar.org/Publications/pdf/161.pdf>.

[9] Jones N, Miller JH. Jatropha curcas: a multipurpose species for problematic sites. ASTAG Technical paper - Land resources, vol. 1. Washington (DC, USA) World Bank; 1992. p. 1-12.

[10] Francis G, Edinger R, Becker K. A concept for simultaneous wasteland reclamation, fuel production, and socioeconomic development in degraded areas in India: need, potential and perspectives of jatropha plantations. Nat Resour Forum 2005;29:12-24.

[11] Kumar A, Sharma S. An evaluation of multipurpose oil seed crop for industrial uses (Jatropha curcas L.): a review. Ind Crops Prod 2008;28(1):1-10.

[12] Achten WMJ, Mathijs E, Verchot L, Singh VP, Aerts R, Muys B. Jatropha biodiesel fueling sustainability? Biofuels Bioprod Biorefin 2007;1:283-91.

[13] Jongschaap REE, Corré WJ, Bindraban PS, Brandenburg WA. Claims and facts on Jatropha curcas L. Wageningen, The Netherlands: Plant Research International, 2007. <http://www.fact-fuels.org/media_en/Claims_and_Facts_ on_Jatropha_-WUR?session=isgsklbna58j7grrfst888n5r7>.

[14] Linnaeus C. Species plantarum. In: Jatropha. Impensis Stockholm: Laurentii Salvii; 1753 . p. $1006-7$.

[15] Dehgan B, Webster GL. Morphology and infrageneric relationships of the genus Jatropha (Euphorbiaceae). University of California Publications in Botany; 1979.

[16] Schultze-Motel J. Rudolf Mansfelds Verzeichnis landwirtschaftlicher and gärtnerischer Kulturpflanzen (ohne Zierpflanzen). Berlin: Akademie-Verlag; 1986.

[17] Münch, E. Die Purgiernuß (Jatropha curcas L.) - Botanik, Ökologie, Anbau. Diploma Thesis. University Hohenheim, Stuttgart; 1986.

[18] Pax F. Euphorbiaceae-Jatropheae. In: Engler A, editor. Das Pflanzenreich IV, vol. 147(42). Leipzig: Verlag von Wilhelm Engelmann; 1910.

[19] Achten WMJ, Verchot L, Franken YJ, Mathijs E, Singh VP, Aerts R, et al. Jatropha bio-diesel production and use. Biomass Bioenergy 2008;32(12):1063-84 
[20] Raju AJS, Ezradanam V. Pollination ecology and fruiting behaviour in a monoecious species, Jatropha curcas L. (Euphorbiaceae). Curr Sci 2002;83:1395-8.

[21] Tewari DN. Jatropha and biodiesel. 1st ed. New Delhi: Ocean books Ltd.; 2007.

[22] Wiehr E. Beiträge zur Kenntnis der Anatomie der wichtigsten Euphorbiaceensamen unter besonderer Berücksichtigung ihrer Erkennungsmerkmale in Futtermitteln. Ph.D. Dissertation, Mathematical-Natural Scientific Faculty, University Hamburg; 1930.

[23] Droit S, Recherches sur la graine et l'huile de Purghère ou Pignon d'Inde (Jatropha curcas L.). Dissertation, Université de Paris, Faculté de Pharmacie, Paris; 1932.

[24] Singh RP. Structure and development of seeds in Euphorbiaceae, Jatropha species. Beitr Biol Pflanz 1970;47:79-90.

[25] Liu HF, Kirchoff BK, Wu GJ, Liao JP. Microsporogenesis and male gametogenesis in Jatropha curcas L. (Euphorbiaceae). J Torrey Botan Soc 2007;134(3):335-43.

[26] Chang-wei L, Kun L, You C, Yong-yu S, Wen-yun Y. Pollen viability, stigma receptivity and reproductive features of $J$. curcas L. (Euphorbiaceae). J Northwest Plant 2007;27(10):1994-2001.

[27] Dhillon RS, Hooda MS, Handa AK, Ahlawat KS, Kumar Y, Subhash, et al. Clonal propagation and reproductive biology in Jatropha curcas L. Indian J Agroforest 2006;8(2):18-27.

[28] Prakash AR, Patolia JS, Chikara J, Boricha G.N. Floral biology and flowering behaviour of Jatropha curcas. In: Expert seminar on Jatropha curcas L. agronomy and genetics, March 26-28. Wageningen, The Netherlands: Published by FACT Foundation; 2007.

[29] Bhattacharya A, Datta K, Datta SK. Floral biology, floral resource constraints and pollination limitation in Jatropha curcas L. Pak J Biological Sci 2005;8(3):456-60.

[30] Qing Y, Ping PD, Biao DZ, Liang WZ, Xiang SQ. Study on pollination biology of Jatropha curcas (Euphorbiaceae). J South China Agricult Univ 2007;28(3): 62-6.

[31] Grant V. Plant speciation. 2nd ed. New York: Columbia University Press; 1981.

[32] Les DH. Breeding systems, population structure and evolution in hydrophilous angiosperms. Ann Mo Bot Gard 1988;75:819-35.

[33] Stebbins GL. Adaptive radiation in angiosperms, pollination mechanisms. Ann Rev Ecol Syst 1970;1:307-26.

[34] Faegri K, Pijl VDL. The principles of pollination ecology. 3rd ed. Oxford: Pergamon Press; 1979.

[35] Wyatt R. Pollinator plant interactions and the evolution of breeding systems. In: Real L, editor. Pollination biology. Florida: Academic Press; 1983. p. 51-95

[36] Fang YM. Plant reproductive ecology. Jinan: Shandong University Press; 1996.

[37] Chang-wei L, Kun L, You C, Yong-yu S. Floral display and breeding system of Jatropha curcas L.. Forum Stud China 2007;9(2):114-9.

[38] Abdelgadira HA, Johnson SD, Stadena JV. Approaches to improve seed production of Jatropha curcas L. South Afr J Botany 2008. doi:10.1016/ j.sajb.2008.01.023

[39] Soontornchainaksaeng P, Jenjittikul T. Karyology of Jatropha (Euphorbiaceae) in Thailand. Thai For Bull 2003;31:105-12.

[40] Carvalho CR, Clarindo WR, Praça MM, Araújo FS, Carels N. Genome size, base composition and karyotype of Jatropha curcas L., an important biofuel plant. Plant Sci 2008;174:613-7.

[41] Singh RK, Kumar AK, Sethi S. Preparation of karanja oil methyl ester; 2006. <http://dspace.nitrkl.ac.in/dspace/bitstream/2080/303/1/ow-rksingh1.pdf $>$.

[42] Gubitz GM, Mittelbach M, Trabi M. Exploitation of the tropical oil seed plant Jatropha curcas L.. Bioresour Technol 1999;67:73-82.

[43] Francis G, Edinger R, Becker K. A concept for simultaneous wasteland reclamation, fuel production, and socio-economic development in degraded areas in India: need, potential and perspectives of Jatropha plantations. Nat Resour Forum 2005;29:12-24.

[44] Kalbande SR, Vikhe SD. Jatropha and Karanj bio-fuel: an alternate fuel for diesel engine. ARPN J Eng Appl Sci 2008;3(1):7-13.

[45] Mukta N, Murthy IYLN, Sripal P. Variability assessment in Pongamia pinnata (L.) Pierre germplasm for biodiesel traits. Industrial Crops Prod 2008. doi:10.1016/i.indcrop.2008.10.002.

[46] Sujatha M. Genetic improvement of Jatropha curcas L. possibilities and prospects. Indian J Agroforest 2006;8(2):58-65.

[47] Sujatha M, Reddy TP, Mahasi MJ. Role of biotechnological interventions in the improvement of castor (Ricinus communis L.) and Jatropha curcas L. Biotechnol Adv 2008;26:424-35.

[48] Singh D. Castor Ricinus communis (Euphorbiaceae). In: Simmonds NW, editor. Evolution of crop plants. London: Longman; 1976. p. 84-6.

[49] Hegde DM, Sujatha M, Singh NB. Castor in India. Hyderabad, India: DOR; 2003.

[50] King AJ, He W, Cuevas JA, Freudenberger M, Ramiaramanana D, Graham IA Potential of Jatropha curcas as a source of renewable oil and animal feed. J Exp Botany 2009. doi:10.1093/jxb/erp025.

[51] Rao GR, Korwar GR, Shanker AK, Ramakrishna YS. Genetic associations, variability and diversity in seed characters, growth, reproductive phenology and yield in Jatropha curcas (L.) accessions. Trees 2008. doi:10.1007/s00468008-0229-4

[52] Burley J, Wood PJ. A manual on species and provenance research with particular reference to the Tropics. Tropical Forestry Papers No. 10.
Department of Forestry, Commonwealth Forestry Institute, University of Oxford; 1976.

[53] Namkoong G, Kang HC, Brouard JS. Tree breeding: principles and strategies Monographs on theoretical and applied genetics, vol. 11. New York: Springer Verlag; 1988.

[54] Zobel BJ, Wyk GV, Stahl P. Growing exotic forests. New York: John Wiley \& Sons; 1988

[55] Dehgan B, Webster GL. Three new species of Jatropha (Euphorbiaceae) from Western Mexico. Madrono 1978;25:30-9.

[56] Prabakaran AJ, Sujatha M. Jatropha tanjorensis Ellis and Saroja, a natura interspecific hybrid occurring in Tamil Nadu, India. Genet Resour Crop Evol 1999;46:213-8.

[57] Makkar HPS, Becker K, Sporer F, Wink M. Studies on nutritive potential and toxic constituents of different provenances of Jatropha curcas. J Agri Food Chem 1997;45:3152-7.

[58] Wani SP, Osman M, D'silva E, Sreedevi TK. Improved livelihoods and environmental protection through biodiesel plantations in Asia. Asian Biotechnol Develop Rev 2006;8(2):11-29.

[59] Kaushik N, Kumar K, Kumar S, Kaushik N, Roy S. Genetic variability and divergence studies in seed traits and oil content of Jatropha (J. curcas L.) accessions. Biomass Bioenergy 2007;31:497-502.

[60] Ginwal HS, Rawat PS, Srivastava RL. Seed source variation in growth performance and oil yield of Jatropha curcas Linn. in Central India. Silvae Genet 2004;53:186-92.

[61] Kun L, Wen-yun Y, Li L, Chun-hua Z, Yong-zhong C, Yong-yu S. Distribution and development strategy for $J$. curcas L. in Yunnan Province, Southwest China. For Stud China 2007;9(2):120-6.

[62] Pant KS, Khosla V, Kumar D, Gairola S. Seed oil content variation in Jatropha curcas Linn. in different altitudinal ranges and site conditions in H.P. India. Lyonia 2006;11(2):31-4.

[63] Sunil N, Varaprasad KS, Sivaraj N, Kumar TS, Abraham B, Prasad RBN Assessing Jatropha curcas L. germplasm in-situ - a case study. Biomass Bioenergy 2008;32:198-202.

[64] Sunil N, Sivaraj N, Anitha K, Abraham B, Kumar V, Sudhir E, et al. Analysis of diversity and distribution of Jatropha curcas L. germplasm using Geographic Information System (DIVA-GIS). Genet Resour Crop Evol 2008. doi:10.1007| s10722-008-9350-X.

[65] Heller J. Untersuchungen über genotypische Eigenschaften und Vermehrungsund Anbauverfahren bei der Purgiernuß (Jatropha curcas L.) [Studies on genotypic characteristics and propagation and cultivation methods for physic nuts (Jatropha curcas L.)]. Dr. Kovac, Hamburg; 1992.

[66] Gohil RH, Pandya JB. Genetic diversity assessment in physic nut (Jatropha curcas L.). Int J Plant Production 2008;2(4):321-6.

[67] Mishra DK. Selection of candidate plus phenotypes of Jatropha curcas L. using method of paired comparisons. Biomass Bioenergy 2008. doi:10.1016 j.biombioe.2008.08.004

[68] Montes LR, Azurdia C, Jongschaap REE, Van Loo EN, Barillas E, Visser R and Mejia L. Global evaluation of genetic variability in Jatropha curcas; 2008. <http://www.pri.wur.nl/NR/rdonlyres/90AF26A1-47D5-4F2F-9E96D413C2933685/70112/PosterMontesHR.pdf>.

[69] Basha SD, Sujatha M. Inter and intra-population variability of Jatropha curcas (L.) characterized by RAPD and ISSR markers and development of populationspecific SCAR markers. Euphytica 2007;156:375-86.

[70] Punia MS. Current status of research and development on jatropha (Jatroph curcas) for sustainable biofuel production in India. In: USDA Globa Conference on Agricultural Biofuels: Research and Economics, 20-22 August, Minneopolis, Minnesota; 2007.

[71] Swarup R. Quality planting material and seed standards in Jatropha. In: Singh B, Swaminathan R, Ponraj V, editors. Proceedings of the biodiesel conference toward energy independence-focus on Jatropha, June 9-10, Rashtrapat Bhawan, Hyderabad, India; 2006. p. 129-35.

[72] Kaushik N, Roy S, Biswas GC. Screening of Indian germplasm of Jatropha curcas for selection of high oil yielding plants. Indian J Agrofores 2006;8(2):54-7.

[73] Paramathma M, Hegde DM, Parthiban KT, Mukta N, Guptha VK, Abraham Y, et al. Scope of tree borne oilseeds as source of vegetable oil and biofuels. In: Singh H, Reddy BN, Murthy IYLN, editors. Souvenir of the national symposium on vegetable oils scenario: approaches to meet the growing demands, January 29-31. Hyderabad, India: Directorate of Oilseeds Research; 2009. p. 47-9.

[74] Sakaguchi S, Somabhi M. Exploitation of Promising Crops of Northeast Thailand Siriphan Offset. Thailand: Khon Kaen; 1987.

[75] Dwimahyani I, Ishak. Induced mutation on jatropha (Jatropha curcas L.) for improvement of agronomic characters variability; 2004. <http://www. digilib.batan.go.id/atom-indonesia/fulltex/v30-n2-7-2004/Ita-DwimahyaniIshak.pdf>.

[76] Pandey RK, Datta SK. Gamma ray induced cotyledonary variabilities in Jatropha curcas L.. J Nucl Agric Biol 1995;24:62-6.

[77] Mayo O. The theory of plant breeding. 2nd ed. Oxford: Oxford University Press; 1987. p. 334

[78] Paramathma M, Reeja S, Parthiban KT, Malarvizhi D. Development of interspecific hybrids in jatropha. In: Singh B, Swaminathan R, Ponraj V, editors. Proceedings of the biodiesel conference toward energy independence-focus on Jatropha, June 9-10, Rashtrapati Bhawan, Hyderabad, India; 2006. p. 13642.

[79] Dehgan B. Phylogenetic significance of interspecific hybridization in Jatropha (Euphorbiaceae). Syst Bot 1984;9(4):467-78. 
[80] Parthiban KT, Kumar RS, Thiyagarajan P, Subbulakshmi V, Vennila S, Rao MG Hybrid progenies in jatropha - a new development. Curr Sci 2009;96(6):815-23.

[81] Basha SD, Sujatha M. Genetic analysis of Jatropha species and interspecific hybrids of Jatropha curcas using nuclear and organelle specific markers. Euphytica 2009;168:197-214.

[82] Rupert EA, Dehgan B, Webster GL. Experimental studies of relationships in the genus Jatropha. L. J. curcas x J. integerrima. Bull Torrey Bot Club 1970;97:321-5.

[83] Sujatha M, Prabakaran AJ. New ornamental jatropha through interspecific hybridization. Genet Resour Crop Evol 2003;50:75-82.

[84] Lakshminarayana M, Sujatha M. Screening of Jatropha species against major defoliators of castor. J Oilseeds Res 2001;18:228-30.

[85] Wei Q, Lu WD, Loao Y, Pan SL, Xu Y, Tang L, et al. Plant regeneration from epicotyl explants of Jatropha curcas. J Plant Physiol Mol Biol 2004;30:475-8.

[86] Li MR, Li HQ Wu GJ. Study on factors influencing agrobacterium-mediated transformation of Jatropha curcas. Fen $\mathrm{Zi} \mathrm{Xi}$ Bao ShengWuXue Bao 2006;39:83-9.

[87] Openshaw K. A review of J. curcas: an oil plant unfulfilled promise. Biomass Bioenergy 2000;19:1-15.

[88] Sujatha M, Mukta N. Morphogenesis and plant regeneration from tissue cultures of J. curcas L.. Plant Cell Tiss Organ Cult 1996;44:135-41.

[89] Jha TB, Mukherjee P, Datta MM. Somatic embryogenesis in Jatropha curcas Linn an important biofuel plant. Plant Biotechnol Rep 2007;1:135-40.

[90] Bhansali R. Somatic embryogenesis and regeneration of plantlets in pomegranate. Ann Bot 1990;66:249-54.

[91] Caetano-Anolles G, Gresshoff PM. DNA markers protocols applications and overviews. New York: Wiley-Liss; 1997.

[92] Okogbenin E, Marin J, Fregene M. An SSR-based molecular genetic map of cassava. Euphytica 2006;147:433-40.

[93] Lespinasse D, Rodier-Goud M, Grivet L, Leconte A, Legnate H, Seguin M. A saturated genetic linkage map of rubber tree (Hevea spp.) based on RFLP, AFLP, microsatellite and isozyme markers. Theor Appl Genet 2000;100:127-38.

[94] Rossetto M. Sourcing of SSR markers from related plant species. In: Henry RJ, editor. Plant genotyping; The DNA fingerprinting of plants. UK: CABI Publishing; 2001. p. 211-24.

[95] Sun Qi-Bao, Li Lin-Feng, Li Yong, Wu Guo-Jiang, Ge Xue-Jun. SSR and AFLP markers reveal low genetic diversity in the biofuel plant Jatropha curcas in China. Crop Sci 2008;48:1865-71.
[96] DBTIndia; 2007. <http://dbtindia.nic.in/Energy_bioscience/Presentations/ TS_4_Dr\%20Nutan\%20Kaushik_TERI_N\%20Delhi.pdf>.

[97] Ganesh Ram S, Parthiban KT, Kumar RS, Thiruvengadam V, Paramathma M. Genetic diversity among Jatropha species as revealed by RAPD markers. Genet Resour Crop Evol 2008. doi:10.1007/s10722-007-9285-7.

[98] Ranade SA, Srivastava AP, Rana TS, Srivastava J, Tuli R. Easy assessment of diversity in Jatropha curcas L. plants using two single-primer amplification reaction (SPAR) methods. Biomass Bioenergy 2008. doi:10.1016/ j.biombioe.2007.11.006.

[99] Gupta S, Srivastava M, Mishra GP, Naik PK, Chauhan RS, Tiwari SK, et al. Analogy of ISSR and RAPD markers for comparative analysis of genetic diversity among different Jatropha curcas genotypes. African J Biotechnol 2008;7(23):4230-43.

[100] Pamidiamarri DVNS, Pandya N, Reddy MP, Radhakrishnan T. Comparative study of interspecific genetic divergence and phylogenic analysis of genus Jatropha by RAPD and AFLP: genetic divergence and phylogenic analysis of genus Jatropha. Mol Biol Rep 2008. doi:10.1007/s11033-008-9261-0.

[101] Reddy MP, Chikara J, Patolia JS, Ghosh A. Genetic improvement of Jatropha curcas adaptability and oil yield. In: Expert seminar on Jatropha curcas L. agronomy and genetics, 26-28 March. Wageningen, The Netherlands, Published by FACT Foundation; 2007.

[102] Leela T, Wani SP, Kannan S, Naresh B, Hoisington DA, Devi P, et al. AFLP-based molecular characterization of an elite germplasm collection of Jatropha curcas L. a biofuel plant. Plant Sci 2009. doi:10.1016/j.plantsci.2009.01.006.

[103] Tong L, Peng SM, Deng WY, Ma DW, Xu Y, Xiao M, et al. Characterization of a new stearoyl-acyl carrier protein desaturase gene from Jatropha curcas. Biotechnol Lett 2006;28:657-62.

[104] Lindqvist Y, Huang W, Schneider G, Shanklin J. Crystal structure of delta 9 stearoyl-acyl carrier protein desaturase from castor seed and its relationship to di-iron proteins. EMBO J 1996;15:4081-92.

[105] Ying Z, Yunxiao W, Luding J, Ying X, Yingchun W, Daihua L, et al. Aquaporin JcPIP2 is Involved in drought responses in Jatropha curcas. Acta Biochim Biophys Sin 2007;39:787-94.

[106] Zhang F, Niu B, Wang Y, Chen F, Wang S, Xu Y, et al. A novel betaine aldehyde dehydrogenase gene from Jatropha curcas, encoding an enzyme implicated in adaption to environmental stress. Plant Sci 2008;174:510-8.

[107] Li M, Li H, Jiang H, Pan X, Wu G. Establishment of an Agrobacteriuimmediated cotyledon disc transformation method for J. curcas. Plant Cell Tiss Organ Cult 2008. doi:10.1007/s11240-007-9320-6. 